\title{
Trans-species transplants raise virus fears
}

San Francisco. With an experiment involving the transplant of baboon bone marrow into HIV patients in prospect, US federal regulators met last week to discuss the risks posed by xenotransplantation - the transplantation of organs or tissue from one species into another - and to collaborate on drawing up safety guidelines.

Government officials say that the potential risk of creating dangerous new viruses through cross-species transplants should be closely examined, and that their agencies can therefore legitimately claim authority over research in the field. They believe that special measures may be necessary, such as federal review of protocols, requirements for disease-free animals and long-term monitoring of transplant recipients.

Last week's three-day meeting in Bethesda, Maryland, was sponsored by the Institute of Medicine (IOM). Officials from the Food and Drug Administration (FDA) and the Centers for Disease Control (CDC) in Atlanta, Georgia, say that they plan to examine cross-species transplants of tissues and organs after enquiries from concerned institutional review boards, medical schools and the public.

In particular, both agencies have been spurred by a proposal from the University of Pittsburgh and the University of California, San Francisco (UCSF), to infuse baboon bone marrow into an HIV patient with the aim of boosting a weakened immune system with one that does not become infected with the virus.

Physicians at UCSF and Pittsburgh were ready to proceed with the experiment in April. But they were stopped by federal regulators, who wanted to examine the social and scientific implications of such work.

"We're not comfortable letting an experi-

\section{Markl to move to MPG}

Munich. Hubert Markl, professor of zoology at the University of Konstanz and the first president of the BerlinBrandenburg Academy of Sciences, has been nominated as the next president of the Max Planck Society (MPG). He will take over from the historian Hans Zacher, who completes his six-year term next June.

Markl, who is 57, was president from 1986 to 1991 of the Deutsche Forschungsgemeinschaft (DFG), which distributes most of the money for university research in Germany. His is the only name put forward for the MPG post, and a postal ballot is expected to confirm his appointment in August.

Meanwhile, Dieter Simon, director of the Max Planck Institute for European Legal History, takes over from Markl as president of the Berlin-Brandenburg Academy this autumn.

A. A. ment like this go forward without some public discussion," says Philip Noguchi, head of the FDA's division of cell and gene therapy. "This is a very seminal case."

The experiment is at the forefront of what experts see as a new medical field with potential for explosive growth. They foresee a future in which baboons (because of their similarity to humans) and pigs (because of their abundance and organ size) would routinely provide bone marrow, hearts, lungs and kidneys for humans. The need is great: of those requiring a heart transplant, half die waiting for a suitable organ.

"The market size is only going to be limited by how good the technology is," says Alex Zisson of the investment analysts Hambrecht \& Quist in New York. He estimates that within a few years, 50,000 pig hearts and 40,000 pig kidneys could be transplanted into humans each year.

But not everyone is enthusiastic. US regulators are concerned that a virus lying dormant in an animal could eventually become aggressive and deadly in a human environment. The research also raises issues about animal rights, as well as the morality of intermingling animal and human tissue.

Louisa Chapman, a medical epidemiologist at the CDC, claimed at last week's meeting that xenotransplants pose infectious risks to the general population, and should be carefully monitored.

She said that a growing body of data suggests that HIV itself may have originated from simian retroviruses introduced to human hosts, where they adapted and spread. She also cited cases such as the Ebola virus, which has emerged from an animal reservoir to kill almost 300 people in a recent outbreak in Zaïre.

More important, an animal virus could combine with a human virus, creating a more pathogenic and virulent microbe, Chapman says. "I cannot dismiss these concerns as mere science fiction."

The federal government acknowledges that the risks of xenotransplants have not been assessed. "We don't want to say we could have regulated this after another pandemic breaks out," says Noguchi. But he adds that in the HIV experiment - as with many other transplants - there are no other life-saving treatments, and that no cases of viral outbreaks from cross-species transplants have so far been documented.

Opponents of xenotransplants also include various animal-rights activists. James Walters, an ethicist from Loma Linda University who supports the HIV experiments, told the IOM meeting that xenotransplants raise a wider question of when it is ethical to kill an animal to save human life.

Baboons are not only close to humans in their genetic make-up but also have complex social lives, Walters argued. "The greater a being approximates undisputed personhood - like you and me - the greater its claim to existence."

But such talk frustrates transplant patients, who are ready to organize against regulatory foot-dragging. "When people are dying, we need to show some urgency and passion," said Jeff Getty, an AIDS activist from San Francisco and a candidate for the baboon bone marrow experiment.

Getty and some researchers fear that a lengthy debate could lead to the suspension of work in cross-species transplantation just when it is showing promise.

Researchers also warn of the dangers of over-regulation. Suzanne Ildstad, who is

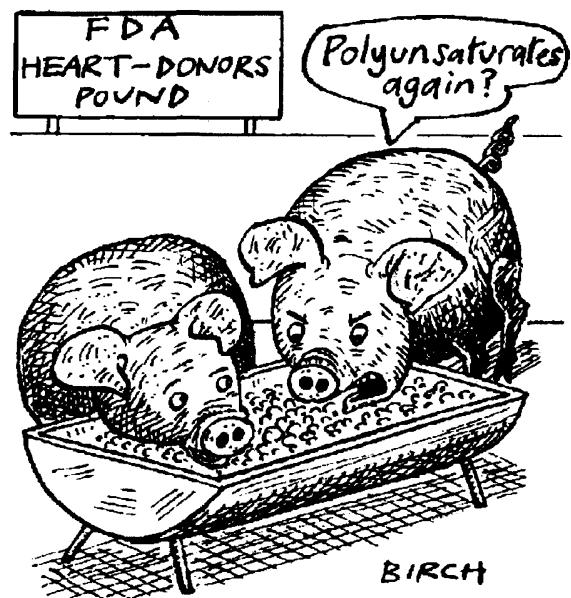

collaborating with UCSF on the AIDS experiment, accepted that the risks of a broad new technology should be considered.

But she expressed concern about the decision of regulatory agencies to become involved in small experiments such as her own. If the FDA had regulated humanto-human transplants during the early years, she said, officials would have stopped the experiments long before they were successful.

FDA and CDC officials plan to have guidelines ready for public comment by the end of the summer. They are preparing a draft for consideration by the FDA's Biological Response Modifiers Advisory Committee at a meeting next week which will also review the HIV/bone marrow protocol.

So far, committee members are moving toward some federal level review of xenotransplants, a registry of recipients, archiving of biological specimens and the quarantine of subjects for a short time where appropriate. The guidelines would also include provision for selection and screening of donor animals, regulators said.

Noguchi of the FDA refuses to predict whether the HIV experiment would win approval. But he said that this would not depend on completion of the guidelines.

Sally Lehrman 